\title{
Phyllobacterium trifolii sp. nov., nodulating Trifolium and Lupinus in Spanish soils
}

Correspondence Encarna Velázquez evp@gugu.usal.es

\author{
Angel Valverde, ${ }^{1}$ Encarna Velázquez, ${ }^{2}$ Félix Fernández-Santos, ${ }^{2}$ \\ Nieves Vizcaíno, ${ }^{2}$ Raúl Rivas, ${ }^{2}$ Pedro F. Mateos, ${ }^{2}$ \\ Eustoquio Martínez-Molina, ${ }^{2}$ José Mariano Igual ${ }^{1}$ and Anne Willems ${ }^{3}$ \\ ${ }^{1}$ Departamento de Producción Vegetal, IRNA-CSIC, Salamanca, Spain \\ 2Departamento de Microbiología y Genética, Lab 209, Edificio Departamental de Biología, \\ Campus Miguel de Unamuno, Universidad de Salamanca, 37007 Salamanca, Spain \\ ${ }^{3}$ Laboratorium voor Microbiologie, Vakgroep Biochemie, Fysiologie en Microbiologie, Universiteit \\ Gent, K.L. Ledeganckstraat 35, B-9000 Gent, Belgium
}

\begin{abstract}
Bacterial strain PETP02 ${ }^{\top}$ was isolated from nodules of Trifolium pratense growing in a Spanish soil. Phylogenetic analysis of the 16S rRNA gene sequence showed that this strain represents a member of the genus Phyllobacterium. However, divergence found with the 16S rRNA gene sequence of the single recognized species of this genus, Phyllobacterium myrsinacearum, indicated that strain PETPO2 ${ }^{\top}$ belongs to a different species. The results of DNA-DNA hybridization, phenotypic tests and fatty acid analyses confirmed that this strain represents a novel species of the genus Phyllobacterium, for which the name Phyllobacterium trifolii sp. nov. is proposed. The type strain is PETP02 ${ }^{\top}$ (=LMG $22712^{\top}=$ CECT $7015^{\top}$ ). This strain was strictly aerobic and used several carbohydrates as carbon source. It was not able to reduce nitrate. Aesculin hydrolysis was negative. It did not produce urease, arginine dihydrolase, gelatinase or $\beta$-galactosidase. The DNA G $+C$ content was 56.4 mol\%. The nod $D$ gene of this strain showed a sequence closely related to those of strains able to nodulate Lupinus. Infectivity tests showed that this strain is able to produce nodules in both Trifolium repens and Lupinus albus.
\end{abstract}

Trifolium pratense is a common legume in temperate soils and establishes effective symbioses with Rhizobium strains. The most common endosymbiont of this legume is Rhizobium leguminosarum biovar trifolii, which induces the formation of indeterminate nodules (Jordan, 1984). This legume belongs to the natural plant cover of many soils in north-west Spain but there are no studies regarding the diversity of bacteria nodulating Trifolium in these soils. During a study of populations of bacteria nodulating Trifolium in several geographical locations we isolated

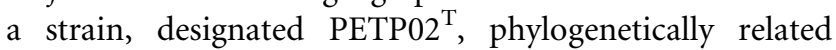
to the genus Phyllobacterium. This genus was described by Knösel (1962) and currently contains one recognized species, since Phyllobacterium rubiacearum was recently reclassified as Phyllobacterium myrsinacearum (Mergaert et al., 2002). The data obtained in the present study show that strain PETP $02^{\mathrm{T}}$ belongs to a novel species of Phyllobacterium.

Published online ahead of print on 6 May 2005 as DOI 10.1099/ ijs.0.63551-0.

The GenBank/EMBL/DDBJ accession numbers for the 16S rRNA and nodD gene sequences of PETPO2 ${ }^{\top}$ are AY786080 and AY786081, respectively.
Strain PETP02 $2^{\mathrm{T}}$ was isolated from $T$. pratense nodules according to the method of Vincent (1970) on YMA medium. Colonies are white, mucoid, translucent and convex following growth on this medium. This strain exhibits a growth rate in YMB (Vincent, 1970) medium similar to that of Rhizobium species (doubling time of $2 \mathrm{~h}$ ).

Strain PETP02 ${ }^{\mathrm{T}}$ was grown on nutrient agar medium for $48 \mathrm{~h}$ to check for motility by phase-contrast microscopy. Cells were gently suspended in sterile water, stained with $0 \cdot 2 \%$ uranyl acetate and examined at $80 \mathrm{kV}$ with a Zeiss EM 209 transmission electron microscope (Peix et al., 2003). Gram reaction of cells was ascertained by staining (Doetsch, 1981). Cells of strain PETP02 ${ }^{\mathrm{T}}$ were Gram-negative, rodshaped, non-sporulating, motile by means of a polar flagellum and commonly observed as single cells.

Strain PETP02 $2^{\mathrm{T}}$ was re-isolated as a pure culture from nodules of Trifolium repens and a single colony was used for all molecular analyses. The nearly complete $16 \mathrm{~S}$ rRNA gene sequence was analysed as described by Rivas et al. (2002). Comparison with sequences from GenBank using the BLAST program (Altschul et al., 1990) indicated that this strain is phylogenetically related to members of the genus Phyllobacterium. Sequences of the new isolate and related bacteria 


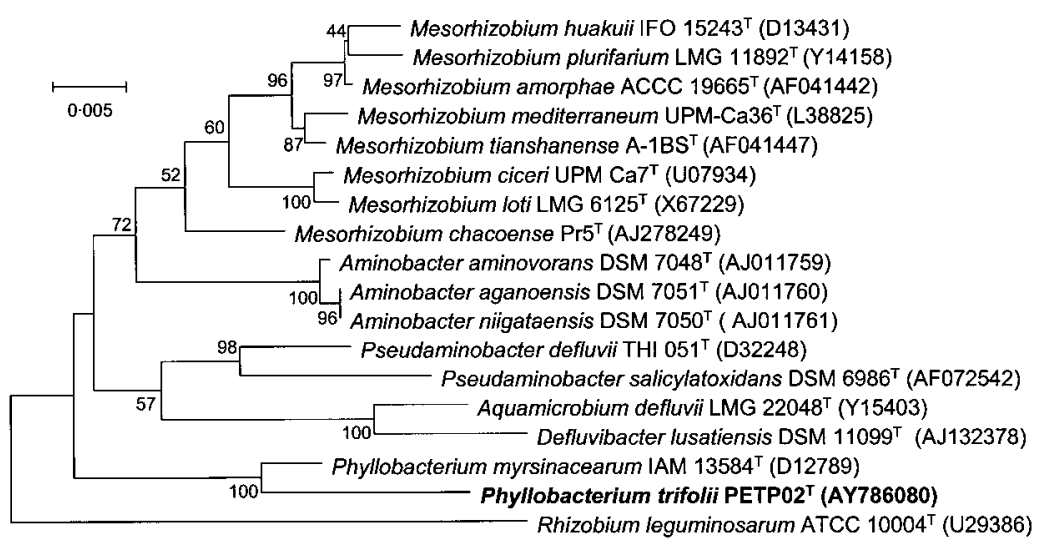

Fig. 1. Comparative sequence analysis of the 16S rRNA gene from Phyllobacterium trifolii $\mathrm{PETPO}^{\top}$ and representative related strains from GenBank. The significance of each branch is indicated by a bootstrap percentage calculated for 1000 subsets. The analysis was based on $1478 \mathrm{nt}$. Rhizobium leguminosarum ATCC $10004^{\top}$ was used as outgroup. Bar, $5 \mathrm{nt}$ substitutions per $1000 \mathrm{nt}$. were aligned using CLUSTAL W software (Thompson et al., 1997). The distances were calculated according to Kimura's two-parameter method (Kimura, 1980). Phylogenetic trees were inferred using the neighbour-joining method (Saitou \& Nei, 1987). Bootstrap analysis was based on 1000 resamplings. The MEGA2 package (Kumar et al., 2001) was used for all analyses. The resulting neighbour-joining tree is shown in Fig. 1. The 16S rRNA gene sequence of strain $\mathrm{PETP} 2^{\mathrm{T}}$ showed $98.0 \%$ similarity to that of P. myrsinacearum, suggesting that it belongs to a different species.

Strain PETP02 ${ }^{\mathrm{T}}$ was subjected to plasmid profile analysis according to Plazinski et al. (1985), except that electrophoresis was performed at $2 \mathrm{~V} \mathrm{~cm}^{-1}$ for $90 \mathrm{~min}$, followed by $3 \mathrm{~V} \mathrm{~cm}^{-1}$ for $60 \mathrm{~min}$ and finally at $6 \mathrm{~V} \mathrm{~cm}^{-1}$ for $3 \mathrm{~h}$. The $175 \mathrm{~kb}$ and $205 \mathrm{~kb}$ plasmids of Sinorhizobium meliloti GR4 (Toro \& Olivares, 1986) were used as size markers and as a positive control for Southern analysis. Plasmid DNA was capillary-transferred to a nylon membrane according to Southern (1975) and immobilized by baking at $80^{\circ} \mathrm{C}$ for $2 \mathrm{~h}$. Oligonucleotide primers were designed to amplify a fragment of the nodD gene conserved among members of the family Rhizobiaceae as described by Rivas et al. (2002). The PCR-amplified fragments of the nodD gene were digoxigenin-labelled with the DIG DNA labelling kit (Roche Diagnostics Corp.) following the manufacturer's instructions and were used as probe. Hybridization was detected with the DIG nucleic acid detection kit (Boehringer Mannheim), using 5-bromo-4-chloro-3-indolyl phosphate (BCIP) and nitro blue tetrazolium (NBT) as substrates for alkaline phosphatase, according to the manufacturer's instructions.

Results from the plasmid profile analysis and the Southern hybridization are shown in Fig. 2. The technique used revealed three plasmids in strain $\operatorname{PETP}^{\mathrm{T}}{ }^{\mathrm{T}}$ (Fig. 2, lane 2). The specific probe detected a nodD gene in the three plasmids of strain PETP02 ${ }^{\mathrm{T}}$ (Fig. 2, lane 4).

A partial sequence of the nodD gene of strain PETP02 ${ }^{\mathrm{T}}$ was obtained from genomic DNA using the method of Rivas et al. (2002). Phylogenetic analysis (Fig. 3) showed that the nodD gene of strain PETP $02^{\mathrm{T}}$ is closely related to that of a novel species of the genus Ochrobactrum that is able to nodulate Lupinus albus (nodD gene sequence similarity of $94.9 \%$; Trujillo et al., 2005).

Taking into account the close phylogenetic relationship between the nodD gene present in strain PETP02 ${ }^{\mathrm{T}}$ and those from strains nodulating Lupinus, we suspected that this strain would also nodulate Lupinus. We therefore tested for nodulation using $T$. repens and $L$. albus as described previously (Velázquez et al., 2001). The strain R. leguminosarum bv. trifolii ATCC 14480 and Bradyrhizobium sp. ISLU35 (Jarabo-Lorenzo et al., 2003) were used as positive controls in $T$. repens and $L$. albus, respectively. As expected, strain PETP02 ${ }^{\mathrm{T}}$ was able to induce nodules in both plants (Fig. 4). The morphology of the nodules formed on T. repens was the same as that of those formed by R. leguminosarum bv. trifolii and they were formed along secondary roots in both cases. However, the nodules formed in L. albus were morphologically different from those formed by Bradyrhizobium sp. ISLU35. The nodules induced by strain PETP02 ${ }^{\mathrm{T}}$ were formed at the intersection of the main and secondary roots, whereas those induced by strain ISLU35 were formed along the secondary roots. Strain PETP $02^{\mathrm{T}}$ formed fewer nodules

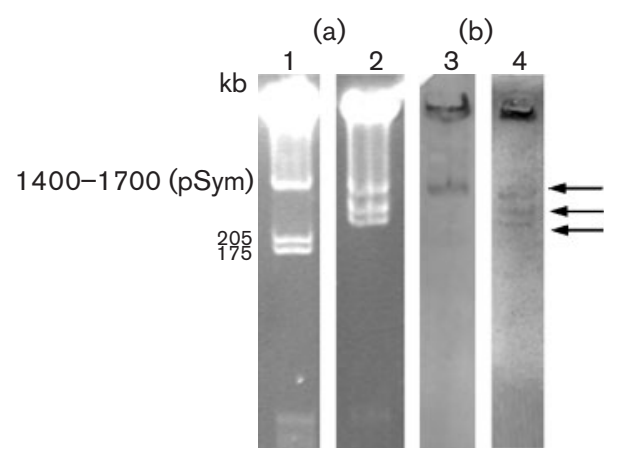

Fig. 2. (a) Plasmid profile in horizontal $0 \cdot 7 \%$ agarose gel: Sinorhizobium meliloti GR4 (lane 1) and strain PETPO2 ${ }^{\top}$ (lane 2). (b) Results of hybridization (marked by arrowheads) using the nodD gene probe: strain GR4 (lane 3) and strain PETP02 ${ }^{\top}$ (lane 2). 


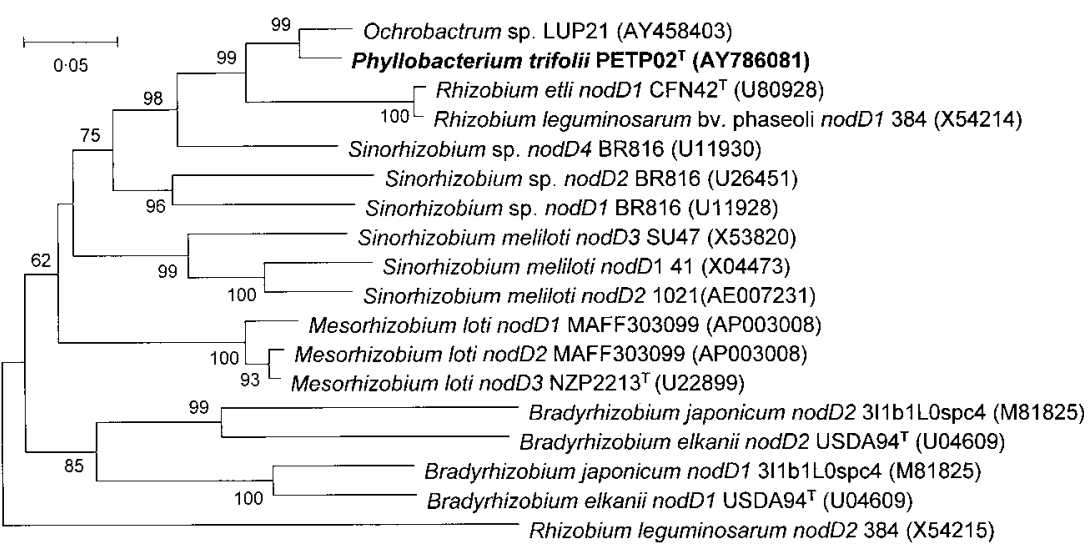

Fig. 3. Comparative sequence analysis of the nodD gene from Phyllobacterium trifolii $\mathrm{PETPO}^{\top}$ and representative related strains from GenBank. The significance of each branch is indicated by a bootstrap percentage calculated for 1000 subsets. The analysis was based on $486 \mathrm{nt}$. Rhizobium leguminosarum 384 was used as outgroup. Bar, 5 nt substitutions per 1000 nt. per plant in both Trifolium and Lupinus plants than did R. leguminosarum bv. trifolii ATCC 14480 and Bradyrhizobium sp. ISLU35, used respectively as positive controls (data not shown).

The DNA G $+\mathrm{C}$ content of strain PETP02 ${ }^{\mathrm{T}}$ as determined by HPLC (Rivas et al., 2003) was $56 \cdot 4 \mathrm{~mol} \%$. This value is lower than the range of $60 \cdot 3-61 \cdot 3 \mathrm{~mol} \%$ reported for P. myrsinacearum (de Smedt \& de Ley, 1977).

DNA-DNA hybridization was performed using a protocol described by Willems et al. (2001) and Rivas et al. (2004). Strain PETP02 ${ }^{\mathrm{T}}$ gave DNA-DNA hybridization levels of $12.0 \%$ with two strains of $P$. myrsinacearum, LMG $1 \mathrm{t} 1$ and LMG $2 \mathrm{t} 2^{\mathrm{T}}$.

Phenotypic characterization of strain PETP02 ${ }^{\mathrm{T}}$ was based on growth with different carbon sources (Bergersen, 1961) as described previously (Velázquez et al., 2001). P. myrsinacearum LMG $2 \mathrm{t} 2^{\mathrm{T}}$ and LMG $1 \mathrm{t} 1$ (formerly P. rubiacearum) were used as reference strains. The temperature range for growth was determined by incubating cultures in YMA medium between 4 and $40{ }^{\circ} \mathrm{C}$. The $\mathrm{pH}$ range was determined in YMA medium with a final $\mathrm{pH}$ between $5 \cdot 0$ and $10 \cdot 0$. Salt tolerance was studied in YMA medium containing 0-5\% (w/v) $\mathrm{NaCl}$. Antibiotic resistance was tested by using the disc diffusion method with the following antibiotics: ampicillin $(2 \mu \mathrm{g})$, erythromycin $(2 \mu \mathrm{g})$, ciprofloxacin $(5 \mu \mathrm{g})$, penicillin (10 IU), polymyxin (300 IU), cloxacillin $(1 \mu \mathrm{g})$, oxytetracycline $(30 \mu \mathrm{g})$, gentamicin $(10 \mu \mathrm{g})$, cefuroxime $(30 \mu \mathrm{g})$ and neomycin $(5 \mu \mathrm{g})$ (Becton Dickinson). The basal medium was YMA (Vincent, 1970) supplemented with $10 \mathrm{~g}$ yeast extract $1^{-1}$. Strain PETP02 $2^{\mathrm{T}}$ and strains LMG $2 \mathrm{t} 2^{\mathrm{T}}$ and LMG 1t1 were also characterized by using API 20NE tests according to the manufacturer's instructions (bioMérieux).
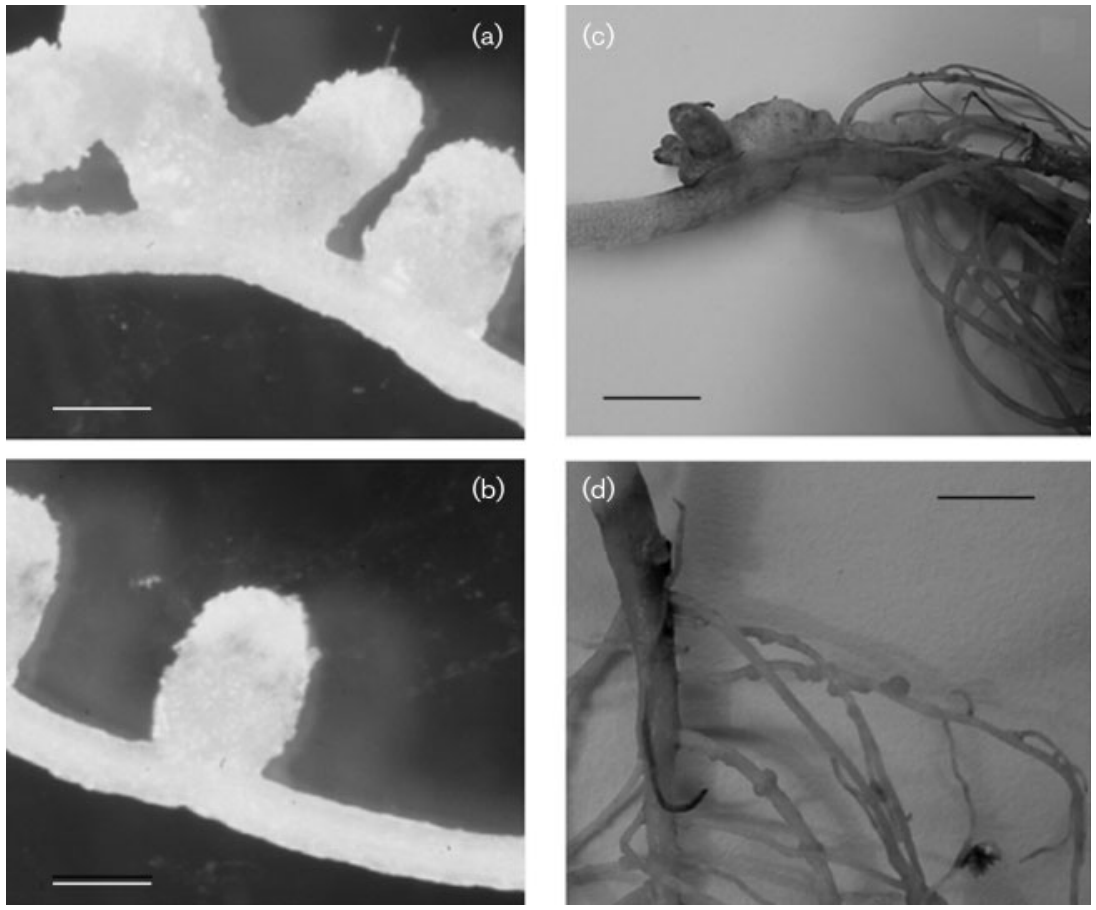

Fig. 4. Nodules induced in Trifolium repens by strain PETPO2 $^{\top}$ (a) and by Rhizobium leguminosarum bv. trifolii ATCC 14480 (b). Bars, $2 \mathrm{~cm}$. Nodules induced in Lupinus albus roots by strain PETPO2 ${ }^{\top}$ (c) and by Bradyrhizobium sp. ISLU35 (d). Bars, $0.2 \mathrm{~cm}$. 
Table 1. Differential phenotypic characteristics of Phyllobacterium trifolii sp. nov. PETPO $2^{\top}$ and $P$. myrsinacearum

+ , Positive; -, negative; w, weak.

\begin{tabular}{|lcc|}
\hline Characteristic & $\boldsymbol{P .}_{\text {trifolii } \text { PETP02 }^{\mathrm{T}}}$ & $\boldsymbol{P}$. myrsinacearum \\
\hline Acid from: & & \\
Sucrose & - & + \\
Rhamnose & $\mathrm{W}$ & + \\
Trehalose & - & + \\
Adonitol & $\mathrm{W}$ & + \\
Raffinose & - & + \\
Citrate assimilation & - & + \\
Resistant to: & & + \\
Polymyxin B & - & + \\
Oxytetracycline & - & + \\
Neomycin & - & \\
\hline
\end{tabular}

The results indicated that strain $\mathrm{PETP} 02^{\mathrm{T}}$ differs from strains of $P$. myrsinacearum in acid production (after 4 days of incubation) from sucrose, trehalose and raffinose, citrate assimilation, and resistance to polymyxin B, oxytetracycline and neomycin (Table 1). Acid production from rhamnose and adonitol was positive in $P$. myrsinacearum but weak in strain PETP02 ${ }^{\mathrm{T}}$. Additional phenotypic characteristics of strain $\mathrm{PETP} 02^{\mathrm{T}}$ are given in the species description below.

We also compared the fatty acid composition of strain PETP02 $2^{\mathrm{T}}$ with those of $P$. myrsinacearum strains LMG 1t 1 and LMG $2 \mathrm{t} 2^{\mathrm{T}}$. Cells were grown for $48 \mathrm{~h}$ on TY medium (Jarvis et al., 1996) and fatty acids were extracted and analysed in duplicate as described by Rivas et al. (2003). The results (Table 2) confirmed previous observations for P. myrsinacearum (Mergaert et al., 2002). As in the case of $P$. myrsinacearum, the novel strain contains $18: 1 \omega 7 c$ as the predominant fatty acid. It differs from $P$. myrsinacearum in that it contains more than $10 \% 16: 0$, more than $15 \%$ $18: 1 \omega 7 c 11 \mathrm{Me}$, small amounts of $17: 0$ and $20: 2 \omega 6,9 c$ (neither of which was detected in P. myrsinacearum), less than 5\% 18:1 2-OH and no 18:0 3-OH.

Our results showed that strain $\mathrm{PETP} 02^{\mathrm{T}}$ is able to nodulate Trifolium and Lupinus, increasing the number of nonrhizobial species that are able to nodulate legumes. This strain can be differentiated genotypically and phenotypically from previously described species and we therefore consider it to represent a novel species, for which the name Phyllobacterium trifolii sp. nov. is proposed.

\section{Description of Phyllobacterium trifolii sp. nov.}

Phyllobacterium trifolii (tri.fo'li.i. L. gen. n. trifolii of clover).

Gram-negative rods, as for the other species of the genus. Colonies are small, pearl white in YMA at $28^{\circ} \mathrm{C}$. Temperature range for growth is $4-37^{\circ} \mathrm{C}$ (optimal growth occurs at $28^{\circ} \mathrm{C}$ ). The $\mathrm{pH}$ range for growth is $6-8$ (optimal growth occurs at $\mathrm{pH} 7$ ). Grows in the presence of $\mathrm{NaCl}$
Table 2. Fatty acid methyl ester (FAME) profiles

Values are mean percentages of total FAMEs. Only fatty acids accounting for more than $1.0 \%$ (mean) are indicated. tr, Trace amount $(<1 \cdot 0 \%)$; ND, not detected.

\begin{tabular}{|c|c|c|c|}
\hline \multirow[t]{2}{*}{ FAME } & \multicolumn{2}{|c|}{ P. myrsinacearum } & \multirow{2}{*}{$\begin{array}{c}\text { P. trifolii } \\
\text { LMG } 22712^{\text {T }}\end{array}$} \\
\hline & LMG 1t1 & LMG $2 \mathrm{t} 2^{\mathrm{T}}$ & \\
\hline $14: 0$ & ND & $\mathrm{ND}$ & $\operatorname{tr}$ \\
\hline $16: 0$ & $5 \cdot 6$ & $4 \cdot 9$ & $14 \cdot 0$ \\
\hline $15: 03-\mathrm{OH}$ & $1 \cdot 3$ & $1 \cdot 9$ & $\operatorname{tr}$ \\
\hline $17: 0$ cyclo & ND & $\mathrm{ND}$ & $\operatorname{tr}$ \\
\hline $17: 0$ & ND & ND & $1 \cdot 2$ \\
\hline $16: 02-\mathrm{OH}$ & $\operatorname{tr}$ & $1 \cdot 4$ & $\mathrm{ND}$ \\
\hline $16: 03-\mathrm{OH}$ & $14 \cdot 4$ & $12 \cdot 8$ & $2 \cdot 4$ \\
\hline $18: 0$ & ND & $\operatorname{tr}$ & $\operatorname{tr}$ \\
\hline $18: 1 \omega 7 c$ & $30 \cdot 9$ & $36 \cdot 3$ & $35 \cdot 8$ \\
\hline $18: 1 \omega 7 c 11 \mathrm{Me}$ & $3 \cdot 0$ & $3 \cdot 8$ & $16 \cdot 8$ \\
\hline $19: 0$ cyclo $\omega 8 c$ & $13 \cdot 9$ & $9 \cdot 0$ & $13 \cdot 4$ \\
\hline $19: 010 \mathrm{Me}$ & $\mathrm{ND}$ & $1 \cdot 0$ & ND \\
\hline $18: 12-\mathrm{OH}$ & $13 \cdot 5$ & $14 \cdot 3$ & $1 \cdot 2$ \\
\hline $18: 03-\mathrm{OH}$ & $1 \cdot 8$ & $1 \cdot 6$ & ND \\
\hline $20: 2 \omega 6,9 c$ & $\mathrm{ND}$ & $\mathrm{ND}$ & $1 \cdot 6$ \\
\hline $20: 0$ & $8 \cdot 7$ & $5 \cdot 8$ & $3 \cdot 8$ \\
\hline Summed feature $2^{\star}$ & $4 \cdot 2$ & $4 \cdot 5$ & $2 \cdot 7$ \\
\hline Summed feature $3^{\star}$ & $1 \cdot 9$ & $2 \cdot 2$ & $4 \cdot 3$ \\
\hline
\end{tabular}

${ }^{*}$ Summed features consist of one or more fatty acids that could not be separated by the Microbial Identification System. Summed feature 2 consists of $12: 0$ aldehyde, iso-16:1 I and/or 14:0 3-OH; summed feature 3 consists of $16: 1 \omega 7 c$ and/or iso-15:0 2-OH.

concentrations up to $3 \%(\mathrm{w} / \mathrm{v})$ although salt is not essential for growth. Isolated from Trifolium pratense, it is able to produce nodules on Trifolium and Lupinus. Nitrate reduction is negative. It does not produce indole gelatinase, $\beta$ galactosidase or arginine dihydrolase. Hydrolysis of urea and aesculin was weak. Produces acid from galactose and arabinose. Acid production from rhamnose and arabitol is weak. Uses glucose, L-arabinose, mannose, mannitol, $N$ acetylglucosamine, maltose and malate as carbon sources. Gentiobiose is weakly used. It does not grow on caproate, adipate, citrate or phenylacetate. Resistant to cloxacillin, penicillin, erythromycin, cefuroxime and ampicillin. Does not grow in the presence of polymyxin B, ciprofloxacin, gentamicin, oxytetracycline or neomycin. The DNA G +C content is $56 \cdot 4 \mathrm{~mol} \%$.

The type strain, PETP02 ${ }^{\mathrm{T}}\left(=\mathrm{LMG} 22712^{\mathrm{T}}=\mathrm{CECT} 7015^{\mathrm{T}}\right.$ ), was isolated from a Trifolium pratense root nodule.

\section{Acknowledgements}

This work was supported by Junta de Castilla y León and DGCYT (Spanish Government). A. W. is grateful to the Fund for Scientific 
Research - Flanders for a position as Postdoctoral Researcher. We thank Renata Coopman and Ilse Vandecandelaere for excellent technical assistance.

\section{References}

Altschul, S. F., Gish, W., Miller, W., Myers, E. W. \& Lipman, D. J. (1990). Basic local alignment search tool. J Mol Biol 215, 403-410.

Bergersen, F. J. (1961). The growth of Rhizobium in synthetic media. Aust J Biol 14, 349-360.

de Smedt, J. \& de Ley, J. (1977). Intra- and intergeneric similarities of Agrobacterium ribosomal ribonucleic acid cistrons. Int $J$ Syst Bacteriol 27, 222-240.

Doetsch, R. N. (1981). Determinative methods of light microscopy. In Manual of Methods for General Bacteriology, pp. 21-33. Edited by P. Gerhardt, R. G. E. Murray, R. N. Costilow, E. W. Nester, W. A. Wood, N. R. Krieg \& G. H. Phillips. Washington, DC: American Society for Microbiology.

Jarabo-Lorenzo, A., Pérez-Galdona, R., Donate-Correa, J. \& 7 other authors (2003). Genetic diversity of bradyrhizobial populations from diverse geographic origins that nodulate Lupinus spp. and Ornithopus spp. Syst Appl Microbiol 26, 611-623.

Jarvis, B. D. W., Sivakumaran, S., Tighe, S. W. \& Gillis, M. (1996). Identification of Agrobacterium and Rhizobium species based on cellular fatty acid composition. Plant Soil 184, 143-158.

Jordan, D. C. (1984). Family III. Rhizobiaceae Conn 1938, $321^{\mathrm{AL}}$. In Bergey's Manual of Systematic Bacteriology, vol. 1, pp. 234-235. Edited by N. R. Krieg \& J. G. Holt. Baltimore: Williams \& Wilkins.

Kimura, M. (1980). A simple method for estimating evolutionary rates of base substitutions through comparative studies of nucleotide sequences. J Mol Evol 16, 111-120.

Knösel, D. (1962). Prüfung von Bakterien auf Fähigkeit zur Sternbildung. Zentralbl Bakteriol Parasitenkd Infektionskr Hyg II Abt 116, 79-100 (in German).

Kumar, S., Tamura, K., Jakobsen, I. B. \& Nei, M. (2001). MEGA: Molecular Evolutionary Genetics Analysis Software. Tempe, AZ: Arizona State University.

Mergaert, J., Cnockaert, M. C. \& Swings, J. (2002). Phyllobacterium myrsinacearum (subjective synonym Phyllobacterium rubiacearum) emend. Int J Syst Evol Microbiol 52, 1821-1823.

Peix, A., Rivas, R., Mateos, P. F., Martínez-Molina, E., RodríguezBarrueco, C. \& Velázquez, E. (2003). Pseudomonas rhizosphaerae sp. nov., a novel species that actively solubilizes phosphate in vitro. Int J Syst Evol Microbiol 53, 2067-2072.
Plazinski, J., Chen, Y. H. \& Rolfe, B. G. (1985). General method for the identification of plasmid species in fast-growing soil microorganisms. Appl Environ Microbiol 48, 1001-1003.

Rivas, R., Velázquez, E., Willems, A., Vizcaíno, N., Subba-Rao, N. S., Mateos, P. F., Gillis, M., Dazzo, F. B. \& Martínez-Molina, E. (2002). A new species of Devosia that forms a nitrogen-fixing root-nodule symbiosis with the aquatic legume Neptunia natans (L. f.) Druce. Appl Environ Microbiol 68, 5217-5222.

Rivas, R., Willems, A., Subba-Rao, N. S., Mateos, P. F., Dazzo, F. B., Martínez-Molina, E., Gillis, M. \& Velázquez, E. (2003). Description of Devosia neptuniae sp. nov. that nodulates and fixes nitrogen in symbiosis with Neptunia natans, an aquatic legume from India. Syst Appl Microbiol 26, 47-53.

Rivas, R., Willems, A., Palomo, J. L., García-Benavides, P., Mateos, P. F., Martínez-Molina, E., Gillis, M. \& Velázquez, E. (2004). Bradyrhizobium betae sp. nov., isolated from roots of Beta vulgaris affected by tumour-like deformations. Int J Syst Evol Microbiol 54, 1271-1275.

Saitou, N. \& Nei, M. (1987). The neighbor-joining method: a new method for reconstructing phylogenetic trees. Mol Biol Evol 4, 406-425.

Southern, E. M. (1975). Detection of specific sequences among DNA fragments separated by gel electrophoresis. J Mol Biol 98, 503-517.

Thompson, J. D., Gibson, T. J., Plewniak, F., Jeanmougin, F. \& Higgins, D. G. (1997). The CLUSTAL_X Windows interface: flexible strategies for multiple sequence alignment aided by quality analysis tools. Nucleic Acids Res 25, 4876-4882.

Toro, N. \& Olivares, J. (1986). Characterization of a large plasmid of Rhizobium meliloti involved in enhancing nodulation. Mol Gen Genet 202, 331-335.

Trujillo, M. E., Willems, A., Abril, A., Planchuelo, A.-M., Rivas, R., Ludeña, D., Mateos, P. F., Martínez-Molina, E. \& Velázquez, E. (2005). Nodulation of Lupinus albus by strains of Ochrobactrum lupini sp. nov. Appl Environ Microbiol 71, 1318-1327.

Velázquez, E., Igual, J. M., Willems, A. \& 9 other authors (2001). Mesorhizobium chacoense sp. nov., a novel species that nodulates Prosopis alba in the Chaco Arido region (Argentina). Int J Syst Evol Microbiol 51, 1011-1021.

Vincent, J. M. (1970). The cultivation, isolation and maintenance of rhizobia. In A Manual for the Practical Study of Root-Nodule Bacteria, pp. 1-13. Edited by J. M. Vincent. Oxford: Blackwell Scientific Publications.

Willems, A., Doignon-Bourcier, F., Goris, J., Coopman, R., de Lajudie, P. \& Gillis, M. (2001). DNA-DNA hybridization study of Bradyrhizobium strains. Int J Syst Evol Microbiol 51, 1315-1322. 